\title{
Bolivian Neocorynura (Hymenoptera: Halictidae): A new species and preliminary key to the fauna
}

\author{
Michael S. Engel \& Allan H. Smith-Pardo
}

\begin{abstract}
A new species of the diverse and complicated augochlorine bee genus Neocorynura Schrottky (Augochlorini: Augochlorina) is described and figured. Neocorynura faceta sp. $n$. is described and figured from the Andes of Bolivia and is most similar to the more northern Andean species, $N$. papallactensis Engel from Ecuador and $N$. iguaquensis Smith-Pardo \& Gonzalez from Colombia, but can be distinguished on the basis of integumental sculpturing and coloration. A preliminary key to the species of Neocorynura known to occur in Bolivia is provided.

Michael S. Engel*, Division of Entomology, Natural History Museum, and Department of Ecology \& Evolutionary Biology, 1501 Crestline Drive, Suite 140, University of Kansas, Lawrence, Kansas 66045, USA. msengel@ku.edu Allan H. Smith-Pardo Entomology, USDA-APHIS-PPQ, Plant Inspection Station, 389 Oyster Point Blvd., Suite 2, South San Francisco, California 94080, USA. allan.h.smith-pardo@aphis.usda.gov
\end{abstract}

\section{Introduction}

The bee genus Neocorynura Schrottky is one of the more diverse and heterogeneous of lineages within the New World halictine tribe Augochlorini (Engel 2000, Michener 2007). The genus comprises at least 91 described living and one fossil species (Engel 1995) and numerous undescribed species distributed from Argentina in the south to Mexico in the north. To date the only faunas of Neocorynura that have been revised are those of Mexico (Smith-Pardo 2005a), Argentina, and Paraguay (Smith-Pardo 2010), in addition to various isolated treatments (e.g., Smith-Pardo 2005b, 2005c, Brosi et al. 2006, Gonzalez et al. 2006, Smith-Pardo \& Gonzalez 2009). Here we describe a new species and provide a preliminary account of the Bolivian fauna. The Bolivian fauna is particularly rich, with at least 20 species (Table 1) but until now without any means of accessing this diversity. Additional species listed in unpublished, online sources are based on misidentifications and only the species included herein have been verified as occurring in the country. A key is here provided for these species.

\section{Material and methods}

Morphological terminology generally follows that of Engel (2000, 2001, 2009) and Michener (2007), with some sculpturing terms adapted from Harris (1979), and with the following abbreviations employed in the description: F, flagellomere; OD, ocellar diameter (based on the median ocellus); S, metasomal sternum; and T, metasomal tergum. Photomicrographs were prepared using a Nikon D1x digital camera attached to an Infinity K-2 long-distance microscope lens. Material is deposited in the California State Collection of Arthropods, Sacramento, California (CSCA). The key provided herein was constructed from direct observation of material for all Bolivian species of the genus, including Vachal's and Cockerell's type specimens (Table 1). 
Table 1. List of species of Neocorynura present in Bolivia and their distribution in other countries, with more precise data (states) when available, in parentheses. All records based on direct observation of specimens as part of Smith-Pardo (2005d, 2010), including holotypes for each. Locality for types indicated by an asterisk $(*))$.

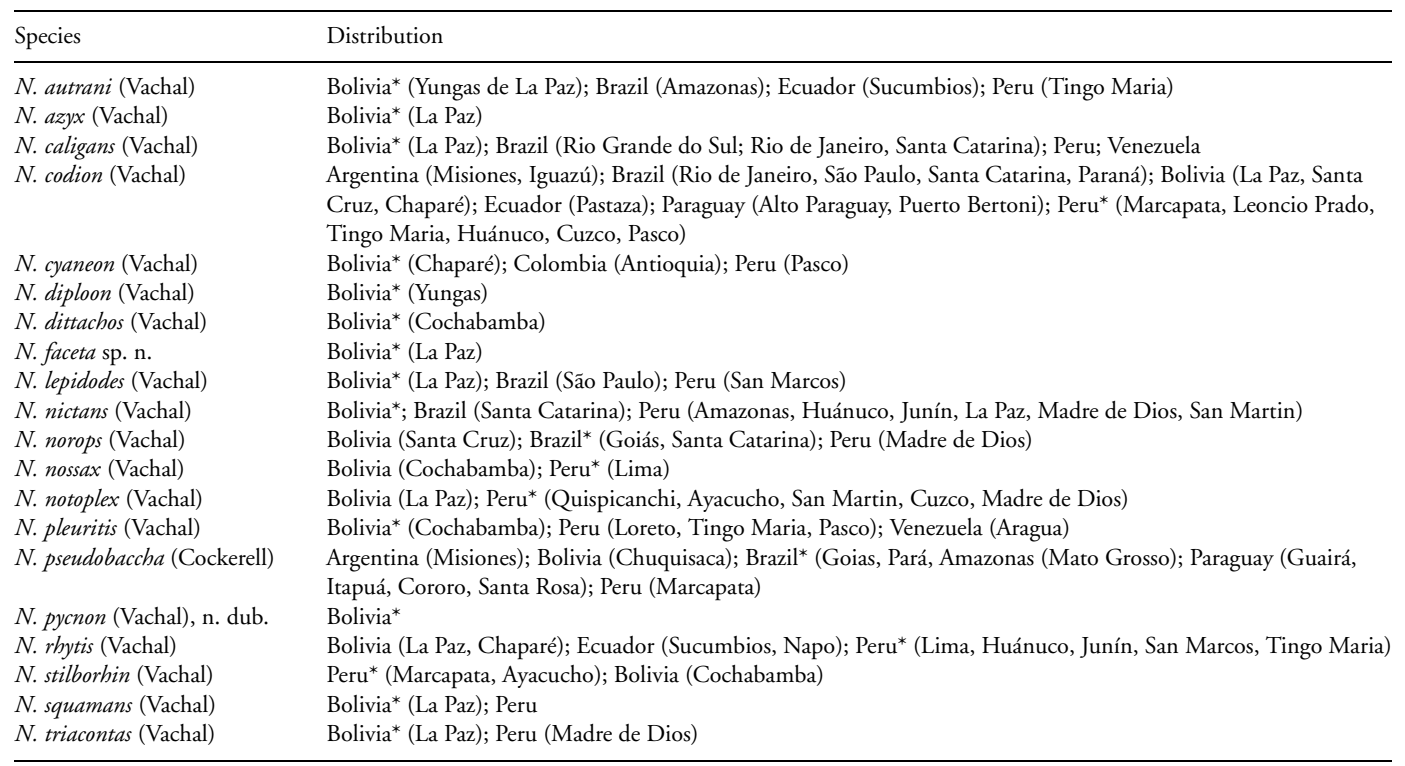

\section{Systematics}

\section{Genus Neocorynura Schrottky Neocorynura faceta sp. $\mathbf{n}$.}

Figs 1-7

Holotype. Female: Bolivia: Prov. La Paz, Cumbre Alto Beni, vicinity of Caranavi, $1685 \mathrm{~m}$, $15^{\circ} 40^{\prime} 19^{\prime \prime} \mathrm{S}, 67^{\circ} 29^{\prime} 35^{\prime \prime} \mathrm{W}$, leg. S.D. Gaimari \& M. Hauser, malaise traps, 7-15.iv.2004 [7-15 April 2004] (CSCA).

\section{Diagnosis}

The new species is superficially very similar to $N . p a-$ pallactensis Engel (Engel 1999) and N. iguaquensis Smith-Pardo \& Gonzalez (Gonzalez et al. 2006), all three having a strigate gena, slightly obtuse epistomal sulcus, and color pattern that is largely dark brown with amber orange and metallic markings. From $N$. papallactensis the new species differs in the striate propodeum (rugulose in the former) (Fig. 3), well defined occipital carina (weak in the former), absence of strong metallic coloration over the mesosoma, particularly the pleura (present in the former) (Fig. 1), and sculpturing of the mesosoma and color pattern of the metasoma (refer to Engel 1999, for N. papallactensis) (Figs 1, 3 and 5). From N. iguaquensis the new species differs in the dark brown second metasomal tergum (amber orange in the former), the contiguously punctured mesoscutum between scattered larger punctures (imbricate between punctures in the former), the coarsely punctured pleura (largely dull and imbricate in the former), striae reaching to apical border except medially (present only in basal twothirds in the former), restriction of metallic highlights to borders of the mesoscutum (more extensive metallic green coloration on the head and mesosoma in the former as described by Gonzalez et al. 2006) (Fig. 3), and bands of tomentum present on second through fifth metasomal terga (weak and restricted to second and third metasomal terga) (Fig. 1).

\section{Description}

\%: Total body length $8.70 \mathrm{~mm}$; forewing length $8.33 \mathrm{~mm}$. Head about as long as wide, length $2.24 \mathrm{~mm}$, width $2.21 \mathrm{~mm}$; upper interorbital distance $1.12 \mathrm{~mm}$, lower interorbital distance $1.04 \mathrm{~mm}$; apical two-thirds of clypeus below lower tangent of compound eyes (Fig. 2); occipital carina present, strong and complete. Anterior border of mesoscutum medially narrowed and projected over pronotal dorsal surface; median and parapsidal lines distinctly impressed; intertegular distance $1.54 \mathrm{~mm}$. Basimetatibial plate with narrowed apex, all borders strongly delimited (Fig. 6); inner metatibial spur with six branches, not including apex of rachis as a branch (Fig. 7). Forewing with cu-a basad basal vein by about twice vein width; $1 \mathrm{~m}$-cu confluent with $1 \mathrm{rs}-\mathrm{m} ; 2 \mathrm{~m}$-cu strongly basad $3 \mathrm{rs}-\mathrm{m}$, latter crossvein weakly bent; marginal cell relatively broad, 


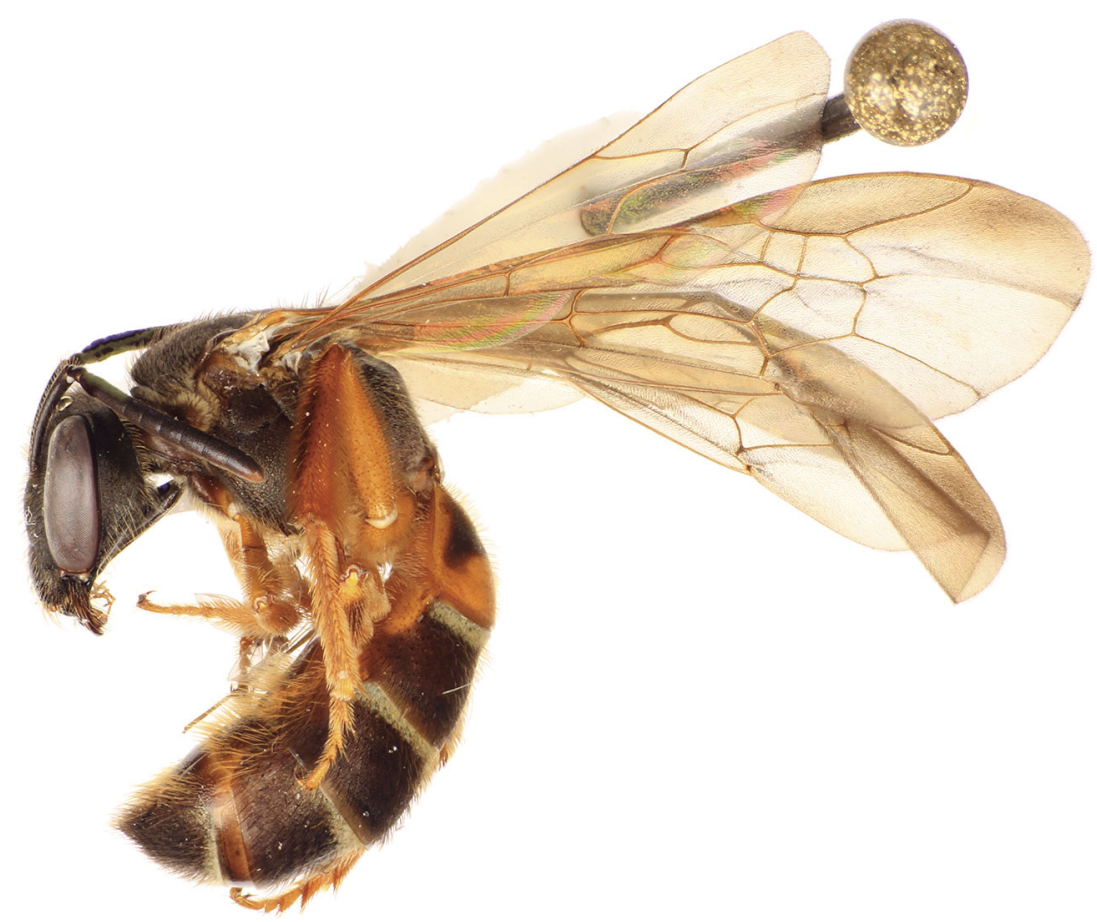

Fig. 1. Lateral habitus of holotype female of Neocorynura faceta sp. n.

with apex minutely truncate (by about vein width) and appendiculate; first submarginal cell about as long as combined lengths of second and third submarginal cells; second submarginal cell about parallel sided; third submarginal cell with anterior border about three-quarters length of posterior border; distal hamuli arranged $4-1-4$ on hind wing. Basal area of propodeum about as long as mesoscutellum.

Clypeus imbricate with scattered, weak punctures separated by $1.5-2.5$ times a puncture width; face coarsely imbricate below level of antennal toruli with small punctures separated by 1-2 times a puncture width; integument blending to contiguously punctured above level of antennal toruli; punctures separated by $0.5-1$ times a puncture width by vertex, with imbricate integument between punctures; gena with small punctures and distinctly strigate, similar on postgena except more imbricate and faintly strigate. Pronotum imbricate with small punctures separated by $1.5-2$ times a puncture width; mesoscutum with contiguous minute punctures intermingled with larger scattered punctures, larger punctures separated by $2-4.5$ times a puncture width, anteriomedially integument blending to strongly imbricate; mesoscutellum and metanotum faintly imbricate with minute punctures separated by $0.5-1$ times a puncture width, intermingled with larger punctures separated by $1-3$ times a puncture width; pleura coarsely imbricate and punctured, punctures separated by less than a puncture width except hypoepimeral area strongly imbricate with small punctures separated by 1-1.5 times a puncture width; basal area of propodeum strongly imbricate with striae radiating from basal margin (Fig. 4), striae reaching apical border except medially. Metasoma strongly imbricate with scattered minute punctures.

Head and mesosoma dark brown to nearly black, without metallic highlights except extreme posterior and lateral borders of mesoscutum with strong bluegreen highlights (Fig. 3), tegula semitranslucent brown, and legs amber orange except procoxa brown and some brown patches on outer surfaces of mesoand metatibiae. Wing veins brown, membranes infumate, more strongly so anteriorly, particularly in marginal cell to wing apex. Metasoma dark brown except first metasomal segment amber brown, first metasomal tergum with basal half brown with strong metallic green to blue-green highlights but brown patch not extending to lateral and basal margins (Fig. 5); terga II-IV with metallic green to bluegreen highlights basally near gradulus and tomentose bands. 

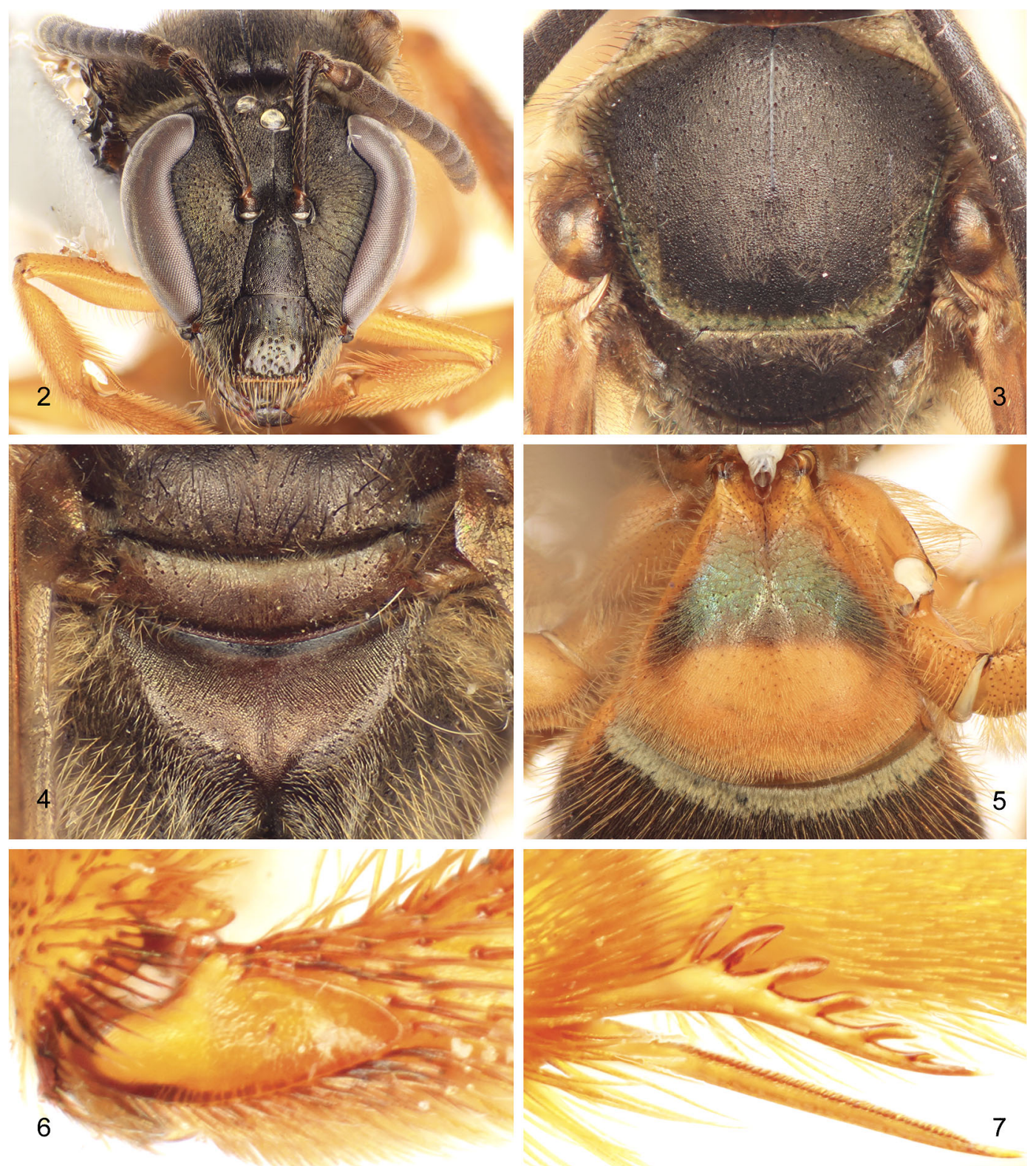

Figs 2-7. Photomicrographs of holotype female Neocorynura faceta sp. n. - 2. Facial aspect. 3. Dorsal view of mesoscutum and mesoscutellum. 4. Dorsal view of metanotum and basal area of propodeum. 5. Dorsal view of first metasomal tergum. 6. Metabasitibial plate. 7. Metatibial spurs, upper is the inner spur, lower is the outer spur.

Pubescence generally fuscous on head, mesosoma, and T2-T5, intermingled with more pale golden setae; pale golden setae predominate on legs and metasomal sterna and distinctly more elongate on latter; pronotal dorsal surface and around pronotal lobe with numerous short, plumose, whitish setae; metasomal terga with distinct, narrow tomentose bands composed of dense, appressed, short, plumose setae basally posterior to gradulus.

Male: Unknown. 


\section{Etymology}

The specific epithet is the Latin term facetus, meaning "elegant", and is used as an adjective.

\section{Preliminary key to the Neocorynura of Bolivia}

The following key represents a preliminary attempt toward a means of identifying those described species of Neocorynura known to occur in Bolivia (Table 1). Many additional species are likely to occur in this region but hitherto there has been no way in which this diverse and complicated genus could be breached by melittologists interested in the fauna. The key is for females only, in part owing to the fact that many species are known only by the female holotype. The sole exception to this is $N$. azyx Vachal for which the only known specimen is a male and, therefore, is not included in the current key. Note also that the holotype female of $N$. pycnon (Vachal), supposedly deposited in the Museum National d'Histoire Naturelle, Paris and also described from Bolivia (Moure and Hurd 1987), could not be located during multiple visits by the authors in 1996 (MSE) and 2004 (AHS-P). Given that it cannot be identified from the original descriptive comments of Vachal (1904) the name is considered a nomen dubium (Smith-Pardo 2005d). The key was constructed from examination of original material for all species.

1. Mesosoma mostly dull, although sometimes with pronotum, margins of mesoscutum, and base of propodeum metallic; T1-T2 mostly non-metallic..................

- Mesosoma mostly metallic green; T1-T2 mostly metallic ................. 12

2. Mesoscutum smooth or punctured, of variable coloration; preoccipital ridge and lateral ridge of pronotum carinate; body length more than $8 \mathrm{~mm}$.................. 3

- Mesoscutum with coarse striae radiating from median line, black with metallic purple and green; preoccipital ridge and lateral ridge of pronotum strongly lamellate; body length not more than $7 \mathrm{~mm} . . . \ldots \ldots . .$. .................... rhytis (Vachal)

3. Forewing marginal cell and sometimes costal margin infuscate ................. 4

- Forewing marginal cell and most of costal margin clear .................... 6

4. Legs dark brown; $\mathrm{T} 1$ dark brown ......... 5

- Legs reddish-orange; T1 mostly reddishorange with metallic area basally......... ....................... N. faceta sp. n.

5. Mesepisternum and mesoscutum smooth and punctate; basal area of propodeum imbricate............... pleuritis (Vachal)
- Mesepisternum and mesoscutum strongly imbricate and punctate; basal area of propodeum sulcate ......... notoplex (Vachal)

6. T1 imbricate or smooth, but distinctly not coarsely punctured and punctures separated by more than a puncture width; T3 mostly dark brown ...................... 7

- T1 smooth, with coarse punctures separated by less than a puncture width; T3 completely metallic .......... squamans (Vachal)

7. Preepisternal groove metallic green or dark brown; basal area of propodeum variable; T3 without basal metallic band or, if present, then yellow or green ........... 8

- Preepisternal groove metallic blue; basal area of propodeum rugulose basally and imbricate distally; T3 with basal metallic band of blue ................. cyaneon (Vachal)

8. Basal area of propodeum not as above; T3 mostly dark brown, only with metallic basal band .......................... 9

- Basal area of propodeum striate close to metanotum, strongly imbricate elsewhere; T3 mostly metallic........ lepidodes (Vachal)

9. Anterior margin of metanotum metallic; basal area of propodeum sulcate or rugulose .............................. 10

- Anterior margin of metanotum dark brown; basal area of propodeum uniformly imbricate .................. nictans (Vachal)

10. Area adjacent to epistomal sulcus metallic; basal area of propodeum sulcate, with lines radiating from midline $\ldots \ldots \ldots \ldots \ldots \ldots 11$

- Area adjacent to epistomal sulcus dark brown; basal area of propodeum rugulose along margin close to metanotum ........ ..................... stilborhin (Vachal)

11. Forewing r-rs shorter than abscissa of Rs forming anterior border of second submarginal cell; strigae nearly vertical on extreme margins of basal area of propodeum ......... .................... diploon (Vachal)

- Forewing r-rs as long as abscissa of Rs forming anterior border of second submarginal cell; strigae nearly horizontal on extreme margins of basal area of propodeum ...... ..................... triacontas (Vachal)

12. Forewing marginal cell infuscate $\ldots \ldots \ldots \ldots 13$

- Forewing marginal cell clear.............15

13. Pronotum only partially covered by minute setae; legs dark brown; T1 smooth or imbricate with minute punctures apically ....... 14 
- Pronotum densely covered by minute setae; legs yellowish; T1 coarsely punctured ..... .................... autrani (Vachal)

14. Metanotum mostly metallic; basal area of propodeum sulcate........... codion (Vachal)

- Metanotum mostly dark brown, margin with mesoscutellum metallic; basal area of propodeum striate ......... caligans (Vachal)

15. Tibiae light orange; $\mathrm{T} 3$ metallic green ..... 16

- Tibiae dark brown; T3 metallic red or orange ............. pseudobaccha (Cockerell)

16. Basal area of propodeum rugulose along margin with metanotum; T1 smooth but densely punctured at least along posterior margin ......................... 17

- Basal area of propodeum uniformly sulcate; T1 smooth with a few scattered punctures ................... nossax (Vachal)

17. Portion of Rs along second submarginal cell same length as Rs + M (i.e., second submarginal cell rectangular in shape); T1 only densely punctured along posterior margin, remainder of surface with scattered punctures ................ norops (Vachal)

- Portion of Rs along second submarginal cell shorter than length of Rs $+M$ (i.e., second submarginal cell trapezoidal); T1 densely punctured ............ dittachos (Vachal)

\section{Acknowledgements}

We are grateful to M. Hauser (CSCA) for providing us with many interesting halictids from Bolivia and elsewhere, to I.A. Hinojosa-Díaz (KU) for assistance with photomicrography, and to two anonymous reviewers for their commentary. This is a contribution of the Division of Entomology, University of Kansas Natural History Museum.

\section{References}

Brosi, B.J., A.H. Smith-Pardo \& V.H. Gonzalez, 2006. A new wood-nesting Neocorynura (Hymenoptera: Halictidae: Augochlorini) from Costa Rica, with notes on its biology. - Zootaxa 1189: 55-68.

Engel, M.S., 1995. Neocorynura electra, a new fossil bee species from Dominican amber (Hymenoptera: Halictidae). - Journal of the New York Entomological Society 103(3): 317-323.

Engel, M.S., 1999. A new species of the bee genus Neocorynura from the Andes of Ecuador (Hymenoptera, Halictidae, Augochlorini). - Spixiana 22(2): 173-178.
Engel, M.S., 2000. Classification of the bee tribe Augochlorini (Hymenoptera: Halictidae). - Bulletin of the American Museum of Natural History 250: 1-89.

Engel, M.S., 2001. A monograph of the Baltic amber bees and evolution of the Apoidea (Hymenoptera). Bulletin of the American Museum of Natural History 259: 1-192.

Engel, M.S., 2009. Revision of the bee genus Chlerogella (Hymenoptera, Halictidae), Part I: Central American species. - ZooKeys 23: 47-75.

Gonzalez, V.H., A.H. Smith-Pardo \& G. Bogotá, 2006. Two new Andean species of Neocorynura (Hymenoptera: Halictidae: Augochlorini) with notes on their biology. - Studies on Neotropical Fauna and Environment 41(3): 197-208.

Harris, R.A., 1979. A glossary of surface sculpturing. Occasional Papers in Entomology 28: 1-31.

Michener, C.D., 2007. The Bees of the World [2 ${ }^{\text {nd }}$ Edition]. Johns Hopkins University Press, Baltimore, MD, $\mathrm{xvi}+[\mathrm{i}]+953$ pp., 20 pls.

Moure, J.S. \& P.D. Hurd, Jr., 1987. An Annotated Catalog of the Halictid Bees of the Western Hemisphere (Hymenoptera: Halictidae). - Smithsonian Institution Press, Washington, DC, vii + 405 pp.

Smith-Pardo, A.H., 2005a. The bees of the genus Neocorynura of Mexico (Hymenoptera: Halictidae: Augochlorini). - Folia Entomologica Mexicana 44(2): 165-193.

Smith-Pardo, A.H., 2005b. A new species of Neocorynura from Ecuador (Hymenoptera: Halictidae), with notes on taxonomy of the genus. - Zootaxa 1051: 55-64.

Smith-Pardo, A.H., 2005c. Systematics and mimicry of the genus Neocorynura: An example of two species from Central America (Hymenoptera: Halictidae). - Acta Zoologica Cracoviensia 48B(1-2): 11-21.

Smith-Pardo, A.H., 2005d. Phylogeny and classification of the bee genus Neocorynura (Hymenoptera: Apoidea: Augochlorini). - Ph.D. Dissertation, University of Kansas, Lawrence, KS, 269 pp.

Smith-Pardo, A.H., 2010. Taxonomic review of the species of Neocorynura (Hymenoptera: Halictidae: Augochlorini) inhabiting Argentina and Paraguay. - Zootaxa 2507: 44-68.

Smith-Pardo, A.H. \& V.H. Gonzalez 2009. A revision of Neocorynura bees of the joannisi group with new geographical records for other Andean species (Hymenoptera: Halictidae, Augochlorini). - Studies on Neotropical Fauna and Environment 44(2): 115-129.

Vachal, J., 1904. Étude sur les Halictus d'Amerique (Hym.). - Miscellanea Entomologica 12: 9-24, 113128, 137-144.

Received: November 19, 2011

Accepted: December 28, 2011 